\title{
Connecting Students' Achievements with Attitudes, the Teachings and Study Habits
}

\author{
Haji Mohammad Redzuan Haji Botty ${ }^{1}$ \\ Hajah Zaitun Hj Mohd Taha² \\ Masitah Shahrill ${ }^{\star}$ \\ Mar Aswandi Mahadi2 \\ 1Sayyidina Umar Al-Khattab Secondary School, Ministry of Education, Brunei Darussalam \\ ${ }^{2}$ Sultan Hassanal Bolkiah Institute of Education, Universiti Brunei Darussalam, Brunei Darussalam \\ *Email: masitah.shahrill@ubd.edu.bn
}

\section{Doi:10.5901/mjss.2015.v6n4s1p113}

\section{Abstract}

The main purpose of this study is to investigate and to determine the linkages of the students' attitudes, teachers' roles in mathematics teaching and students' study habits that may contribute to students' achievement in mathematics. Questionnaires were given to 37 students from two levels (Year 9 and Year 10) ages 14 to 16 from one of the secondary schools in Brunei Darussalam. The questionnaires were designed specifically for the students to find the correlations between the students' Mathematics Achievement (MA) and three main variables. The three variables used in the questionnaire are attitudes towards mathematics, Mathematics Teachings (MT) and Student's Study Habits (SH). The variable on attitudes towards mathematics was bi-dimensional with both positive and negative statements. The positive and negative items for attitudes were designated as two sub-variables called Positive Attitudes (PA) and Negative Attitudes (NA). The findings revealed that students' positive attitudes have a significant and positive correlation with their mathematics achievement and the students' positive attitudes come from the teachers' lessons delivery and interaction with the students. The study was based in the school settings that involved students and teachers. Future study should explore on other external factors such as parents' involvement and study habits at home.

Keywords: mathematics, Brunei Darussalam, students' achievement

\section{Introduction}

Mathematics is known amongst students as one of the most difficult subjects in school, and it is common to see poor mathematics results from primary and secondary schools in Brunei Darussalam (Botty \& Shahrill, 2014, 2015; Salam \& Shahrill, 2014; Shahrill, 2009; Shahrill et al., 2014; Shahrill \& Clarke, 2014; Yassin et al., 2015). From the Ministry of Education's statement reported by Rajak (2014) in the local newspaper, more than half of the students at 11 primary schools failed their mathematics in their first assessment before sitting for their Primary School Assessment (PSR) public examination. This is quite worrying not only with the primary students but also at secondary level. The Ministry of Education and schools have introduced several numeracy projects to improve the mathematics subjects but why do the mathematics performances in the primary and secondary schools in Brunei Darussalam remain low?

There are several past research studies done locally that investigated the possible factors for the students' poor achievement in mathematics. Students were found to have a wide range of problems with mathematics. The problems have been observed to be due to lack of proper understanding of mathematical language and misinterpretation of mathematical concepts (Anit \& Suffolk, 2001; Chin \& Clements, 2001; Mundia, 2010; Vaiyatvutjamai \& Clements, 2004). A study by Sarwardi and Shahrill (2014) has shown that the students were struggling with fundamental concepts in mathematics and the level of misconceptions had a significant effect on students' achievement in tests or examinations. The students' mathematical misconceptions may originate from the primary level and develop even more robust misconceptions in the secondary level. The students' errors and misconceptions were resulted from inattentiveness of the classroom teachers. Meanwhile, another study suggested that mathematics anxiety and test stress related negatively with mathematics achievement (Hamid et al., 2013). Anxiety and stress are high throughout a student's time in school since tests and examinations produce much anxiety, tension and stress. Careless mistakes, misconceptions, anxiety, stress, lack of motivation and language are some factors that other researchers have studied that may contribute to poor 
achievement in mathematics. These studies were conducted on students as well as teachers using various quantitative and qualitative instruments.

There are several research studies that also show a link between attitudes and mathematics achievement. Attitudes are defined as positive or negative emotional dispositions (Aiken, 2000; McLeod, 1992; Yee, 2010). Here, the students' emotions play an important role in developing their attitudes. An important factor in developing attitudes in mathematics was the emotive response of a person to a situation. Situations that lead to positive or enjoyable emotive responses will affect a person's positive beliefs and attitudes and the opposite effect with negative emotive responses (Ellerton \& Clements, 1994; Sparrow \& Hurst, 2010; Way \& Relich, 1993).

Mathematics teachers are responsible in delivering the content knowledge to the students. Using effective teaching techniques can help students to learn and understand the mathematical concepts during lessons. The role of teachers in classroom becomes one of the basic issues in educational research since their interactions with students affect learning and conceptual development (Akyüz \& Berberoglu, 2010; Brophy \& Good, 1986; Mahadi \& Shahrill, 2014; Salam \& Clarke, 2014; Shahrill \& Clarke, 2014). The importance of effective teaching and its impact on student achievement are evident in past research studies. According to $\operatorname{Kaur}(2008,2009)$ and Murray $(2011)$, a teacher should be able to give a 'good' mathematics lesson and students must be motivated to learn the subject. Students will only be interested to learn mathematics if the teacher is 'good'. A good teacher must also really know what they are teaching and gives examples that the students can relate to (Kaur, 2008, 2009; Murray, 2011).

Another possible factor that may contribute to students' mathematics achievement is their study habits. According to Ozsoy et al. (2009), study habit is the amount and kinds of study routines the student used during a regular period of study occurred in a conducive environment. The amount of work given by the teacher such as classwork, homework or projects should help the students to improve their results. However, the students' study habits at home are quite difficult to monitor. Study habits, attitudes and academic performance are found to have a positive relation (Ozsoy et al., 2009; Prociuk \& Breen, 1974).

\section{Purpose of Study}

The purpose of this study is to investigate other possible factors that may contribute to students' low achievement in mathematics. The possible factors that will be investigated are the students' attitudes, teachers' roles in mathematics teaching and students' study habits. The main objective of this present study was to determine the linkages that students' attitudes, mathematics teaching and students' study habits have with mathematics achievement in a sample of Year 9 and Year 10 students from a secondary school in Brunei Darussalam.

However, there are limitations to this present study. Only two levels (Year 9 and Year 10) from one secondary school were used as sample in this study and this does not represent the results of the whole students population in Brunei Darussalam. Since the students achievement were based on their Mid Year Exam results, we cannot conclude that the results reflect the students' overall performance since the exam papers were not the same for the two levels. The performance of students in the exam should not be used to measure students' performance in mathematics as a whole since they were administered with different topics. The participants in this study will be taking International General Certificate of Secondary Education (IGCSE) Ordinary (O) Level Mathematics Core syllabus that represents the majority of the students. Meanwhile, there are a few students taking the Extended IGCSE syllabus and also the Brunei-Cambridge General Certificate of Education (BCGCE) O Level Mathematics. Other secondary schools in Brunei mostly offered the GCE mathematics and a few are taking the core or extended versions of the IGCSE mathematics.

\section{Methodology}

Questionnaires were given to the students at one of the secondary schools in Brunei Darussalam. The questionnaires were designed specifically for the students to find the correlations between the students' Mathematics Achievement (MA) and three main variables. The three variables used in the questionnaire are attitudes towards mathematics, Mathematics Teachings (MT) and Student's Study Habits (SH). The variable on attitudes towards mathematics was bi-dimensional with both positive and negative statements. The positive and negative items for attitudes were designated as two subvariables called Positive Attitudes (PA) and Negative Attitudes (NA). There were 14 positively phrased items and the other 8 items were negatively phrased. MT consisted of 17 items and the SH had 11 items. All the items had 4-points Likert-type scales ranging from 1 (disagree a lot) to 4 (agree a lot). The negatively phrased items were reversed scored. The items were adapted from Trends in International Mathematics and Science Study (TIMSS) 2011 students' questionnaire on attitudes, Laguna State Polytechnic University's survey on students' study habits and Boston College's 
students' mathematics survey. The alpha coefficient of Cronbach yielded 0.818 for the 50 -item questionnaire.

There were 37 students participated in this study. The students were from two levels (Year 9 and Year 10) ages 14

to 16. The students' Mid Year Exams results were used as measurement of mathematics achievement. The mean mark was 47.7 with a standard deviation of 18.1. The marks were expressed as percentages. Table 1 below represents the descriptive statistics of the students' mathematics achievement. The students were grouped into above average $(N=20)$ and below average $(\mathrm{N}=17)$.

Table 1. Descriptive Statistics

\begin{tabular}{cccccc}
\hline & $\mathrm{N}$ & Minimum & Maximum & Mean & Std. Deviation \\
\hline Marks & 37 & 2 & 81 & 47.70 & 18.095 \\
Valid N (listwise) & 37 & & & & \\
\hline
\end{tabular}

\section{Results and Discussions}

The main aim of this research was to correlate students' mathematics achievement with students' positive and negative attitudes, mathematics teaching and students' study habits as shown in Table 2 below. There is only statistically significant value $(p<0.01)$ on the correlation between mathematics achievement and PA with a moderate positive correlation, $r=0.42$. The other correlations were proven to be very weak and were not significant. From the correlation between students' MA and PA, the results show that the students need to have positive attitudes in order to perform well in mathematics.

Table 2. Mathematics achievement versus attitudes, teaching and study habits

\begin{tabular}{cccccc}
\hline & & PA & NA & MT & SH \\
\hline \multirow{3}{*}{ MA } & Pearson correlation & $0.42^{* *}$ & -0.15 & 0.17 & 0.19 \\
& Sig. (2-tailed) & 0.01 & 0.38 & 0.315 & 0.27 \\
& $N$ & 37 & 37 & 37 & 37 \\
\hline \multirow{2}{**}{ Correlation is significant at the 0.01 level (2-tailed) } & & &
\end{tabular}

Past research studies have also linked positive attitudes with motivation. According to Deci and Ryan (1985) and Yee (2010), motivation can be categorised into three broad categories, namely amotivation, extrinsic motivation and intrinsic motivation. Amotivation occurs when individuals feel that an activity has no value, do not feel competent to complete a task or do not expect any desirable outcome from the activity. Extrinsic motivation refers to the desire to engage in an activity because it leads to an unrelated outcome caused by externally imposed rewards or punishments or internalise the reasons for their behaviours and impose their own rewards or constraints (Deci, 1972; Hayamizu, 1997; Spaulding, 1992; Vallerand et al., 1992; Yee, 2010). Intrinsic motivation refers to an inner desire to accomplish a task, and pleasure is derived in the process (Berlyne, 1965; Deci, 1975; Yee, 2010). Results have shown that students who have positive attitudes toward mathematics are intrinsically motivated. The students' intrinsic motivation can be enhanced by creating opportunities for students to have control over their learning environments and increasing students' perceived competence in completing tasks.

Table 3 shows the overall correlation with all the variables in this study. PA was found to have significant correlation with all the subscales. This shows that PA is also linked with NA, MT and SH. PA has a weak negative correlation with NA and also has a weak positive correlation with $\mathrm{SH}$. However, there is a strong positive correlation between PA and MT. This shows that the students' positive attitudes come from the teachers' lessons delivery and interaction with the students.

Table 3. Inter-correlations of subscales and mathematics achievement (MA)

\begin{tabular}{lccccc}
\hline & 1 & 2 & 3 & 4 & 5 \\
\hline Mathematics Achievement (MA) & 1 & $0.420^{* *}$ & -0.148 & 0.170 & 0.186 \\
Positive Attitudes (PA) & $0.420^{* *}$ & 1 & $-0.376^{\star}$ & $0.734^{* *}$ & $0.388^{\star}$ \\
Negative Attitudes (NA) & -0.148 & $-0.376^{\star}$ & 1 & -0.184 & $-0.460^{* *}$ \\
Mathematics Teaching (MT) & 0.170 & $0.734^{* *}$ & -0.184 & 1 & $0.489^{* *}$ \\
Study Habits (SH) & 0.186 & $0.388^{*}$ & $-0.460^{* *}$ & $0.489^{* *}$ & 1 \\
\hline
\end{tabular}

**. Correlation is significant at the 0.01 level (2-tailed).

*. Correlation is significant at the 0.05 level (2-tailed).

A teacher plays an important role not only in teaching the students but also motivating the students. Students need to be motivated intrinsically and extrinsically in order to have positive attitudes in mathematics. It is common to see teachers in Brunei to give rewards for good behaviour and punishment for unwanted response. However, Yee's (2010) research 
study had shown that extrinsic motivation and achievement was almost non-existent and extrinsic rewards and punishments may not be useful in improving students' achievement in mathematics. Hence, teachers must sustain the students' intrinsic motivation through other methods. Murray (2011) mentioned that social and emotional factors in teaching were also important to students. A good mathematics teacher must have positive characteristics such as caring, respectful, patient and approachable. In addition, a good mathematics teacher should create a classroom environment where students feel comfortable and actively seek help to enhance their own learning.

The students were divided into two groups, the Above Average $(N=20)$ and Below Average $(N=17)$ in order to further analyse the students' responses to items in the questionnaire. The 4-point Likert scales were combined into two nominal categories, Agree and Disagree. The data was then compared between the responses made between the above average and below average students.

Table 4. Comparison between above average and below average students for PA

\begin{tabular}{ccccc}
\hline \multirow{2}{*}{ Items } & \multicolumn{2}{c}{ Above Average } & \multicolumn{2}{c}{ Below Average } \\
\cline { 2 - 5 } & $\%$ Agree & \% Disagree & \% Agree & $\%$ Disagree \\
\hline 1a & 100 & 0 & 88 & 12 \\
1d & 100 & 0 & 88 & 12 \\
1f & 95 & 5 & 94 & 6 \\
1g & 100 & 0 & 94 & 6 \\
2a & 90 & 10 & 94 & 6 \\
2d & 90 & 10 & 94 & 6 \\
2h & 80 & 20 & 82 & 18 \\
3a & 95 & 5 & 76 & 24 \\
3d & 90 & 10 & 59 & 41 \\
3f & 75 & 25 & 29 & 71 \\
3i & 100 & 0 & 94 & 6 \\
3j & 100 & 0 & 100 & 0 \\
3k & 100 & 0 & 100 & 0 \\
3l & 80 & 20 & 94 & 6 \\
\hline
\end{tabular}

Referring to Table 4 above, item $3 f$ shows a different response between the above average and below average students. Majority of the below average students (70\%) disagreed to the statement "I am good at working out difficult mathematics problems" when $75 \%$ of the above average students agreed. This shows that the below average students were not confident in solving difficult tasks. Table 5 shows the comparison of the above average and below average responses to MT. These two factors (PA and MT) are being focused in this discussion since there was a strong positive correlation between PA and MT.

Table 5. Comparison between above average and below average students for MT

\begin{tabular}{|c|c|c|c|c|}
\hline \multirow{2}{*}{ Items } & \multicolumn{2}{|c|}{ Above Average } & \multicolumn{2}{|c|}{ Below Average } \\
\hline & $\%$ Agree & $\%$ Disagree & $\%$ Agree & $\%$ Disagree \\
\hline $2 c$ & 100 & 0 & 94 & 6 \\
\hline $2 \mathrm{e}$ & 95 & 5 & 88 & 12 \\
\hline $2 f$ & 90 & 10 & 88 & 12 \\
\hline $2 \mathrm{~g}$ & 100 & 0 & 100 & 0 \\
\hline $2 i$ & 85 & 15 & 82 & 18 \\
\hline $2 \mathrm{j}$ & 90 & 10 & 88 & 12 \\
\hline $2 \mathrm{k}$ & 45 & 55 & 41 & 59 \\
\hline 2I & 90 & 10 & 94 & 6 \\
\hline $2 m$ & 45 & 55 & 47 & 53 \\
\hline $2 \mathrm{n}$ & 95 & 5 & 94 & 6 \\
\hline 20 & 100 & 0 & 94 & 6 \\
\hline $2 p$ & 80 & 20 & 88 & 12 \\
\hline $2 q$ & 55 & 45 & 65 & 35 \\
\hline $2 r$ & 75 & 25 & 82 & 18 \\
\hline $2 s$ & 85 & 15 & 94 & 6 \\
\hline $2 \mathrm{t}$ & 10 & 90 & 12 & 88 \\
\hline $3 \mathrm{~g}$ & 75 & 25 & 47 & 53 \\
\hline
\end{tabular}


Item $3 g$ gave a different response when compared between the above and below average students. For the above average students, $75 \%$ agreed while $53 \%$ of the below average students disagreed to item $3 \mathrm{~g}$. This item stated "My teacher thinks I am good at mathematics" is connected with item 3f. Teachers thought that the students were good at mathematics when actually the students had difficulty with mathematics problems. There are two possibilities, either the students did not confront the teachers with their difficulty or teachers ignored the students who had difficulty in mathematics. If the students did not confront their teacher, this means that they were afraid to approach and ask for help. A teacher's positive characteristics and ability to teach the students until they understand the concepts are essential in a classroom. Students need to approach the teachers when they do not understand. A caring and approachable teacher can help these students and eventually will eliminate students' errors and misconceptions. Students will also be motivated and be interested in learning mathematics.

One possible reason for students who could not do or find some mathematical problems difficult is that they do not understand the mathematical concepts. Teachers should not ignore these students. Not all students understand the concepts that are being taught at the same pace. Some understand easily but others may take some time to grasp the concepts. In the classroom, no two students are the same. Each student is unique and because of this not all students can learn to use the same method. Each and every one of them is different. It is a fact that students come from different cultural backgrounds, they have different interests and hobbies and their ability are not the same. Teachers need to observe the differences and they cannot cater to all the students' differences with just one method of teaching. Differentiated learning is a strategy where all students will be able to achieve the learning objectives through different strategies that cater to their different needs and capabilities.

Studies also found that hands-on and interactive work in a supportive and relaxing environment appeared to improve students' understanding of mathematics. At the same time, they can increase students' confidence in their own abilities. The feeling of empowerment enabled the students to develop positive attitudes to learning mathematics (Jennison \& Beswick, 2010). Teachers should also motivate students to learn through the use of a variety of approaches. The effectiveness of teaching relies on the various teaching techniques and the use of teaching aids that can stimulate learners to think critically and creatively. The use of ICT is another one way to stimulate and at the same time motivate the students. The World Wide Web consists of many interactive and stimulating demonstrations of mathematical concepts ready for the teachers and students. Students can use the Internet independently to discover new knowledge or information through discovery learning.

\section{Conclusion}

In this study, students' positive attitudes were found to have a significant and positive correlation with their mathematics achievement. Teachers play an important role in building students positive attitudes inside and also outside the classroom. Since students have different abilities and capabilities, teachers need to cater to each and every student's needs. The main purpose is to help students understand better the mathematical concepts being taught in the classroom. Teachers must also have positive characteristics so that students can approach them with confidence if they have difficulty in solving tasks or they have not fully understand the concepts that are being taught.

Students need to be motivated in order to build their attitudes. Rewards and punishment are two extrinsic motivators to help students but students need to be self-motivated. Students who are intrinsically motivated tend to have positive attitudes. Through self-discovery learning and collaboration among peers, students will have the satisfaction in what they are doing and hence will have positive attitudes in mathematics. Teachers must also use other teaching strategies that will help students intrinsically motivated such as giving more project-based learning. Through group work activities, students can collaborate and share ideas among their peers to solve mathematical problems. The satisfaction of solving a problem can help the students to be intrinsically motivated.

This present research study has the potential to be explored further. The study was based in the school settings that involved students and teachers. Other external factors may also contribute to the students' poor achievement in mathematics such as parents' involvement and study habits at home. It should also be mentioned here that the purpose of this study is not to find fault or put blame, instead we need to work together as a community to help the students in their study and pursuing their future careers.

\section{References}

Anit, S., \& Suffolk, J. (2001). Investigating understanding by primary six pupils of word problems involving multiplication and division. In K. Y. Wong \& M. A. K. Clements, Energising science, mathematics, and technical education for all: Proceedings of the sixth 
annual conference of the Department of Science and Mathematics Education (pp. 290-300). Gadong: University of Brunei Darussalam.

Aiken, L. R. (2000). Psychological Testing and Assessment (10th ed.). Boston, MA: Allyn and Bacon.

Akyüz, G., \& Berberoglu, G. (2010). Teacher and Classroom Characteristics and Their Relations to Mathematics Achievement of the Students in the TIMSS. New Horizons in Education, 58(1), 77-95.

Berlyne, D. E. (1965). Curiosity and education. In J. D. Krumboltz (Ed.), Learning and the Educational Process. Chicago, IL: Rand McNally.

Brophy, J., \& Good, T. L., (1986). Teacher behavior and student achievement. In M.C. Wittrock (Ed), Handbook of Research on Teaching, (3rd ed.). New York: Macmillan.

Botty, H. M. R. H., \& Shahrill, M. (2014). The impact of gagné, vygotsky and skinner theories in pedagogical practices of mathematics teachers in Brunei Darussalam. Review of European Studies, 6(4), 100-109.

Botty, H. M. R. H., \& Shahrill, M. (2015). Narrating a teacher's use of structured problem-based learning in a mathematics lesson. Asian Journal of Social Sciences \& Humanities, 4(1), 156-164.

Chin, K. S., \& Clements, M. A. K. (2001). O-level students' understanding of lower secondary school geometry. In W. K. Yoong \& M. A. K. Clements, Energising science, mathematics, and technical education for all: Proceedings of the sixth annual conference of the Department of Science and Mathematics Education (pp. 213-222). Gadong: University of Brunei Darussalam.

Deci, E. L. (1972). Intrinsic motivation, extrinsic reinforcement, and inequity. Journal of Personality and Social Psychology, 22, 113-120.

Deci, E. L. (1975). Intrinsic Motivation. New York, NY: Plenum.

Deci, E. L., \& Ryan, R. M. (1985). Intrinsic motivation and self-determination in human behavior. New York, NY: Plenum Press.

Ellerton, N., \& Clements, M. A. (1994). Fostering mathematical attitudes and appreciation. Adelaide: AAMT.

Hamid, M. A., Shahrill, M., Matzin, R., Mahalle, S., \& Mundia, L. (2013). Barriers to mathematics achievement in Brunei secondary school students: Insights into the roles of mathematics anxiety, self-esteem, proactive coping and test stress. International Education Studies, 6(11), 1-13.

Hayamizu, T. (1997). Between intrinsic and extrinsic motivation: Examination of reasons for academic study based on the theory of internalization. Japanese Psychological Research, 39(2), 98-108.

Jennison, M., \& Beswick, K. (2010). Student attitude, student understanding and mathematics anxiety. Paper presented at the Annual Meeting of the Mathematics Education Research Group of Australasia, Fremantle, Western Australia.

Kaur, B. (2008). Teaching and learning of mathematics: What really matters to teachers and students? ZDM, 40(6), 951-962.

Kaur, B. (2009). Characteristics of good mathematics teaching in Singapore grade 8 classrooms: A juxtaposition of teachers' practice and students' perception. ZDM, 41(3), 333-347.

Mahadi, M. A. H., \& Shahrill, M. (2014). In pursuit of teachers' views on the use of textbooks in their classroom practice. International Journal of Education, 6(2), 149-158.

McLeod, D. B. (1992). Research on affect in mathematics education: A reconceptualization. In D. Grouws (Ed.), Handbook of research on mathematics teaching and learning (pp. 575-596). New York, NY: Macmillan.

Mundia, L. (2010). Problems in Learning Mathematics: Comparison of Brunei Junior High School Students in Classes with and without Repeaters. Journal of Mathematics Research, 2(3), 150-160.

Murray, S. (2011). Secondary students' descriptions of "good" mathematics teachers. Australian Mathematics Teacher, 67(4), $14-21$.

Ozsoy, G., Memis, A., \& Temur, T. (2009). Metacognition, study habits and attitudes. International Electronic Journal of Elementary Education, 2(1), 154-166.

Prociuk, T. J., \& Breen, L. J. (1974). Locus of control, study habits and attitudes, and college academic performance. The Journal of Education, 88.

Rajak, W. (2014, May 20). Over 50\% of pupils failed maths. The Brunei Times. Retrieved from http://www.bt.com.bn/

Salam, N. H. A., \& Shahrill, M. (2014). Examining classroom interactions in secondary mathematics classrooms in Brunei Darussalam. Asian Social Science, 10(11), 92-103.

Sarwadi, H. R., \& Shahrill, M. (2014). Understanding students' mathematical errors and misconceptions: the case of Year 11 repeating students. Mathematics Education Trends and Research 2014 (2014), 1-10.

Shahrill, M. (2009). From the general to the particular: Connecting international classroom research to four classrooms in Brunei Darussalam. Unpublished doctoral dissertation, University of Melbourne, Melbourne, Australia.

Shahrill, M., Abdullah, N. A., Yusof, J., \& Suhaili, A. S. (2014). Informing the practice of teaching mathematics in upper primary classes. In I. Sahin, S. A. Kiray, \& S. Alan (Eds.), Proceedings of the International Conference on Education in Mathematics, Science \& Technology (pp. 168-172). Konya, Turkey: Necmettin Erbakan University.

Shahrill, M., \& Clarke, D. J. (2014). Brunei teachers' perspectives on questioning: Investigating the opportunities to 'talk' in mathematics lessons. International Education Studies, 7(7), 1-18.

Sparrow, L., \& Hurst, C. (2010). Effecting affect: Developing a positive attitude to primary mathematics learning. Australian Primary Mathematics Classroom, 15(1), 18-24.

Spaulding, C. L. (1992). Motivation in the Classroom. New York, NY: McGraw-Hill.

Vaiyatvutjamai, P., \& Clements, M. A. K. (2004). Analysing errors made by middle school students on six linear inequa- tions tasks. In I. P. A. Cheong, H. S. Dhindisa, I. J. Kyeleve, \& O. Chukwu, Globalisation trends in science, mathematics and technical education: Proceedings of the annual conference of the Department of Science, Mathematics and Technical Education (pp. 173-182). Gadong: University of Brunei Darussalam. 
Vallerand, R. J., Pelletier, L. G., Blais, M. R., Briere, N. M., Senecal, C., \& Vallieres, E. F. (1992). The Academic Motivation Scale: A measure of intrinsic, extrinsic, and amotivation in education. Educational and Psychological Measurement, 52, 1003-1017.

Way, J., \& Relich, J. (1993). Development of positive attitudes in mathematics: The perspective of pre- service teachers. In B. Atweh, C. Kanes, M. Carss \& G. Booker (Eds), Contexts in mathematics education: Proceedings of the 16th annual conference of the Mathematics Education Research Group of Australiasia, (pp. 581-586). Brisbane: MERGA.

Yassin, N. H. M., Shahrill, M., Jaidin, J. H., \& Harun, H. Z. H. (2015). The Effects of Streaming on Secondary School Students' Achievements in Additional Mathematics. European Journal of Social Sciences, 46(2), 148-158.

Yee, L. S. (2010). Mathematics Attitudes and Achievement of Junior College Students in Singapore. Paper presented at the Annual Meeting of the Mathematics Education Research Group of Australasia, Freemantle, Western Australia. 